\title{
The Model of the Formation and Implementation of the Creative and Innovative Potential of the Russian System of Higher Education
}

\author{
Aleksandr Pavlovich Gorbunov, Natalya Nikolaevna Gorbunova, Ekaterina \\ Vladimirovna Efimova, Sofiya Georgievna Kilinkarova ${ }^{1}$
}

\begin{abstract}
:
Theoretical interpretation and applied projection of the dynamics of the innovative role of higher education as a scientific basis for developing a model of the formation and implementation of the creative and innovative potential of the Russian higher education system are one of the most controversial problems of the modern Russian and world economy. The research is based on the principles of the system, system-situational and integrative approaches, macroeconomic and microeconomic analysis, methods of the structural and functional characteristics of the processes under study, research and projection of economic relations in their real dynamics with respect to their historical and logical origin.
\end{abstract}

Key Words: Russian higher education, knowledge economy, competency-based economy

\footnotetext{
${ }^{1}$ Pyatigorsk State Linguistic University, Pyatigorsk, Russian Federation
} 


\section{Introduction}

The modern economy is characterized by the increase in the system pressure of three main objective trends - innovation, competitiveness and globalization. At the same time, all of them have a single substance as an integrated foundation - the generation of new knowledge, its industrial development and large-scale distribution. However, it is not quite understood that the emerging knowledge economy, in its deepest essence, acts as economy of the knowledge novelty (innovation) and, accordingly, of the general transformative competences. It expresses the transition to a new, intellectual and innovative way of reproduction, requiring a single universal productive-economic process and the corresponding flexible product that fundamentally changes the status and functions of the system dynamics of higher education in the overall process and the mechanism of social reproduction.

The essence and significance of substantial changes in the reproductive mechanism are still insufficiently revealed. The reason is that it has not been brought to the forefront that under the new conditions the main strategic instrument for the implementation of innovative, competitive and globalized vectors of the dynamics of the national economy is the advanced development of such sector of social production, which definitely includes all three stages of the innovative algorithm. This sector is particularly represented by institutions of higher education - the only sphere wherein the functioning mechanism objectively includes generating, disseminating and applying new knowledge as intellectual and innovative capital in its basic varieties.

In this regard, there is a need for a qualitative change in the conceptual and methodological basis for the development of modern economic theory, which takes it to a new theoretical and methodological ground - focused no longer on maintaining the traditional economic dynamics, but on continuous reproduction of the dynamics of innovation.

Today it is generally accepted that there has been established a stable functional interaction between the level of education of the collective worker, the quality of social labor productivity and the growth of the national income - as a direct correlation between these three parameters, based, in particular, on the level of education, including higher education. However, there has not been yet developed a crucially important idea that a new, innovative era generates different qualitative determination of higher education and, therefore, highly skilled workers, "produced" only in higher education institutions (in modern economic theory indicating the category of medium high human capital). New requirements for human capital as a necessarily enriched by intellectual and innovative component, creates tensions between traditionally understood functions of university education and modern more applied utilitarian interpretation of its functions, in connection with which both the economic practice and modern theory ensure the compromise between them. But in fact, there is a need for a synergistic solution of the contradiction between these 
approaches that provide a transition to the methodology and practice of the systematic innovation dynamics of higher education. This can develop a model of the University of the New Generation, which gives the most adequate response to the challenges of the new era, since it is based on the continuous renewal of creativity and innovation in all the processes and relationships of labor and management.

At the same time the increasingly widespread position is that the modern university is a kind of "business enterprise" for the production, dissemination and application of knowledge, similar to any other type of business (in terms of the basic principles of its organization and management) leading to the emergence of new economic industries and sectors. But in fact, systemic innovation dynamics as a qualitatively new economic relation is intended to profoundly transform the type of university, not only in terms of processes and relations of the production and transfer of new knowledge, but also in terms of processes and relations of organization and management, which determines the regularity of innovation management formation as a universal system of special economic relations, distributed, in their turn, on innovative business processes in all sectors of the economy.

Furthermore, the changes include not only the organizational and economic level of economic relations, but also the deep social and economic level - the level of property relations that transforms the system of economic interests and implies qualitative changes of the collective worker of the system of higher education and the economic system as a whole.

Theoretical interpretation and applied projection of the dynamics of the innovative role of higher education as a scientific basis for developing a model of the formation and implementation of the creative and innovative potential of the Russian higher education system are one of the most controversial problems of the modern Russian and world economy, as far as the issue, in fact, is about the strategic resources of the country in the era of national economy globalization.

The following scientists made a significant contribution to the development of these problems: Berezovsky, A.P., Borlikov, G.M., Borovskaya, M.A., Voloshin, I.S., Gavrilov, A.L., Gozhenko, K.N., Gorev, V.K., Davydov, Y.S., Dadaev, L.M., Dobrynin, V.I., Efremov, L.G., Zhukov, V.I., Ivanov, A.E., Ioshkin, A.I., Katrovich, A.P., Klyachko, T.L., Kozlov, A.A., Krasnozhenova, J.F., Kudryannikov, E.M., Kuzminov, Y.I., Kutsev, G.F., Livanov, D.V., Lunev, A.P., Melikhova, N.V., Ovchinnikov, R.V., Plaksit, S.I., Postnikov, E.S., Pugach, V.D., Ramirez, A.P., Rubina, V.Y., Sadovnichy, V.A., Sazonov, B.A., Smolentsova, A.L., Solonitsyn, V.A., Stepanov, V.I., Subetto, A.I., Tishkin, G.A., Frumin, I.D., Fursenko, A.A., Shusharina O.P. etc.

Among the foreign studies particularly noteworthy are the works by B.R. Clark, J. Ropka, S. Slaughter and L.L. Leslie, H. Ettskovitsa, J. Angell and E. Dangerfield. 


\section{Methodology}

This study is based on the fundamental principles of the classical economic school about the role of knowledge, science and education in economic development and modern approaches to the study of the nature and characteristics of higher education as an innovative factor of socio-economic transformation, presented in the latest works of domestic and foreign authors. The research used the conceptual approaches dedicated to:

- the specificity of the interrelation of higher education and the main sectors of the real economy;

- the interconnection of information and knowledge;

- the role of knowledge as a specialized and versatile tool, which has a productive force;

- the role of economic interests in the implementation of effective management of the socio-economic systems and the functioning of the system of stimulation and motivation;

- the economic content of innovation and innovativeness;

- the essential foundations of socio-economic governance (management);

- the structure and functions of the collective worker of the society;

- distinguishing two leveled subsystems in the system of economic relations of the society;

- organizational and economic relations and socio-economic relations.

This research is based on the principles of the system, system-situational and integrative approaches, macroeconomic and microeconomic analysis, methods of the structural and functional characteristics of the processes under study, research and projection of economic relations in their real dynamics with respect to their historical and logical origin.

The instruments and methodical framework of the study include general scientific principles and approaches of the economic research:

- dialectical principles of the ascent from the concrete to the abstract, from the single - to the general, and on this basis - to the projection of the ways to improve the existing practice;

- the principles of the unity of the historical and logic, analysis and synthesis, induction and deduction, differentiation and integration;

- the subject-object and subject-subject characteristics of economic processes and relations;

- the graphic, statistical and ranked methods of the processing of empirical material.

\section{Results and Discussion}

The twenty-first century has become the time of the formation and reassessment of priorities and principles of the further development of the Russian higher education 
system, which brought some results by the years 2012-2014. Analyzing the statistics of the beginning of the twenty-first century, in particular, its first decade, Klyachko (2011) concludes that the Russian Federation is a country with a high level of education. The 2002 census showed that 462 people per 1000 people, aged 15 years and older, have higher education (complete and undergraduate), as well as vocational secondary education, while according to the last Soviet census in 1989, this figure was 322 people (i.e. their share increased by 1.4 times from 1989 to 2002.). In the year 2009, the proportion of persons with higher education (including postgraduate) among the employed population amounted to $28.2 \%$ (by this indicator) Russia ranks fourth in the world, trailing only Norway, the USA and the Netherlands), and with vocational secondary education $-27.1 \%$. The total number is $55.3 \%$, which is over a half.

By the number of the university students, which is 523 per 10,000 people Russia holds the second place in the world after the USA. Furthermore, if we add the number of students of secondary vocational education (i.e. tertiary education, according to the international classification) to this amount, we will get a total number of 673 students per 10,000 people, and by this indicator Russia ranks first (Klyachko, 2011).

In general, in the twenty-first century there can be distinguished three formative stages of the modern Russian higher education system until 2014 (Table 1).

Table 1. Stages of the formation and development of the modern Russian higher education system in the XXI century

\begin{tabular}{|l|l|l|l|}
\hline Stage & \multicolumn{1}{|c|}{ Characteristic } & \multicolumn{1}{c|}{ Specificity } & \multicolumn{1}{c|}{ Results } \\
\hline $\mathbf{1 9 9 9 -}$ & $\begin{array}{l}\text { The formation of the } \\
\text { educational market in } \\
\text { Russia, the establishment of } \\
\text { market principles of the } \\
\text { educational system, the } \\
\text { creation of the non- } \\
\text { government sector of } \\
\text { education, the changing of } \\
\text { the structure and industry } \\
\text { specialization of educational } \\
\text { institutions }\end{array}$ & $\begin{array}{l}\text { The development of } \\
\text { private universities, the } \\
\text { formation of new kinds } \\
\text { of educational services, } \\
\text { the increase in } \\
\text { quantitative indicators } \\
\text { of the education } \\
\text { system, market } \\
\text { saturation of } \\
\text { educational services } \\
\text { and their } \\
\text { diversification }\end{array}$ & $\begin{array}{l}\text { The establishment of } \\
\text { the foundations of the } \\
\text { market-organized } \\
\text { system of education, } \\
\text { the expansion of the } \\
\text { network and structure } \\
\text { of higher educational } \\
\text { institutions }\end{array}$ \\
\hline $\mathbf{2 0 0 6 -}$ & $\begin{array}{l}\text { The beginning of the } \\
\text { formation of the integrated } \\
\text { institutions (federal } \\
\text { universities), preparation for } \\
\text { the transition to the Bologna } \\
\text { system of education }\end{array}$ & $\begin{array}{l}\text { structural organization, } \\
\text { management and } \\
\text { financial components } \\
\text { of higher education } \\
\text { institutions }\end{array}$ & $\begin{array}{l}\text { The formation of five } \\
\text { federal universities, } \\
\text { the implementation of } \\
\text { the national project } \\
\text { "Education" }\end{array}$ \\
\hline
\end{tabular}




\begin{tabular}{|l|l|l|l|}
\hline $\mathbf{2 0 1 0 -}$ & $\begin{array}{l}\text { The entry to the Bologna } \\
\text { process, the changing of the } \\
\text { structure of higher education } \\
\text { (bachelor and master } \\
\text { courses), the enhancement } \\
\text { of the role of the educational } \\
\text { services quality, the } \\
\text { implementation of the } \\
\text { competence-based approach } \\
\text { to education }\end{array}$ & $\begin{array}{l}\text { The formation of } \\
\text { research universities } \\
\text { and universities of the } \\
\text { entrepreneurial type, } \\
\text { the enhancement of the } \\
\text { role of researches and } \\
\text { innovations in the } \\
\text { system of higher } \\
\text { education, the } \\
\text { strengthening of the } \\
\text { relationship between } \\
\text { universities and the } \\
\text { business community }\end{array}$ & $\begin{array}{l}\text { The improvement of } \\
\text { quality, the reduction } \\
\text { oniversities, the } \\
\text { implementation of } \\
\text { public-private } \\
\text { partnerships in higher } \\
\text { vocational education }\end{array}$ \\
& &
\end{tabular}

In the twenty-first century, there was a transition in Russia to more constructive reforms, stability, consolidation and signs of growth in the economy. For example, in the year 2000 economic growth was $7-7.5 \%$, GDP growth $-7.6 \%$, growth in industrial production - 9.2\% (Abramenko \& Ilyina, 2001). In 1999-2004 and subsequent years there was an increase in gross domestic product (Figure 1). This had a positive impact on higher education.

Figure 1. Dynamics of GDP in the period 1999-2013 based on Statistical Yearbook of Russia (2014)

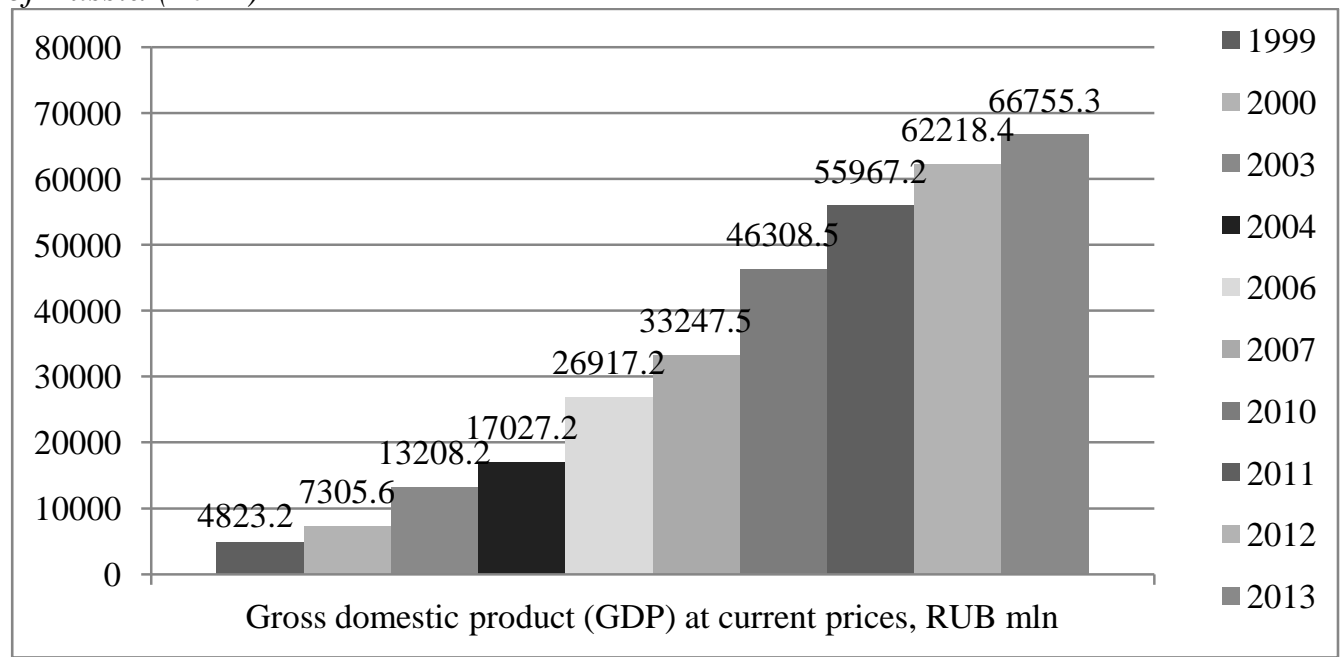

The legislative and regulatory framework in the field of higher education, elaborated in the 1990s, was further developed and expanded. In 2001, the President of the Russian Federation V.V. Putin in his annual Address to the Federal Assembly noted, "...We must clearly set out the limits for free education, ensure fair and guaranteed access to this education and also create an adequate legal foundation for fee-paying education" (Annual Address of the President of the Russian Federation to the Federal Assembly of the Russian Federation, 2001) 
In the 2000/01 academic year, Russia had 312 public universities, 165 academies and 130 institutes, and in 2011/12, there were 634 public universities, 169 academies and 123 institutes (Figure 2).

Figure 2. Public higher education institutions by type in the 2000/01-2011/12 academic years based on data from Education in figures (2013)

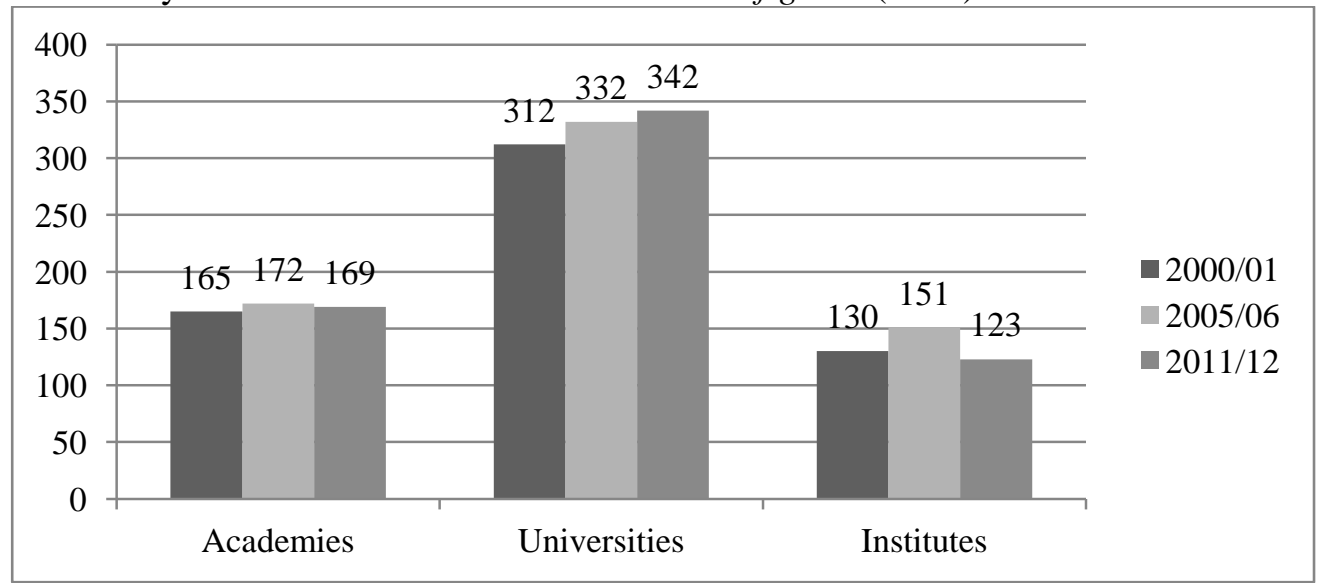

In addition, as mentioned above, the field of private higher education was well formed by the beginning of the twenty-first century (the number of private universities increased to 413 in the 2005/2006 academic year and to 446 - in 2011/12) (Figure 3).

Figure 3. Dynamics of the sector of public and private education institutions at the turn of the 21st century based on data from Education in figures (2013)

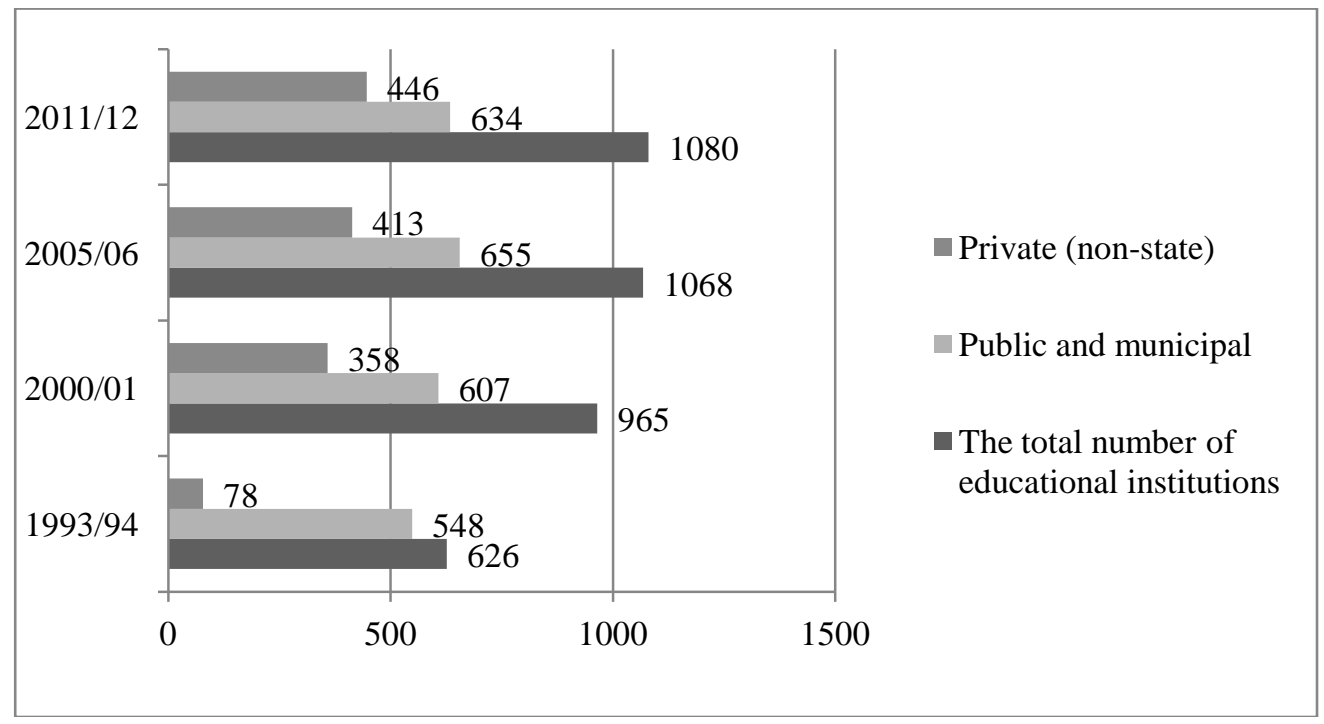


The dynamics of change in 2000-2014 covered different aspects of higher education: funding modalities; teaching and learning process indicators; the integration of education and research; training and retraining of the teaching staff; the improvement of the quality assessment of educational institutions; the definition of the principles of admission quotas; the adaptation of Russian higher education to the new pan-European settings; the restructuring of the federal ministry responsible for higher education; the transition to new classifications; the formation of new types of universities (federal, national, research) etc.

There were also some positive changes in the financial and economic situation. Thus, the share of consolidated budget expenditures on education as a percentage of GDP increased to $3.9 \%$ in 2006 compared to $2.9 \%$ in 2000 , and by 2010 , this figure was already $4.3 \%$ (Table 2 ).

Table 2. Dynamics of public funding of higher education based on data from Indicators of education (2013)

\begin{tabular}{|l|c|c|c|c|c|c|c|c|c|}
\hline \multicolumn{1}{|c|}{ Indicator } & $\mathbf{2 0 0 4}$ & $\mathbf{2 0 0 5}$ & $\mathbf{2 0 0 6}$ & $\mathbf{2 0 0 7}$ & $\mathbf{2 0 0 8}$ & $\mathbf{2 0 0 9}$ & $\mathbf{2 0 1 0}$ & $\mathbf{2 0 1 1}$ \\
\hline \multicolumn{7}{|c|}{ Expenditure on education: } \\
\hline $\begin{array}{l}\text { Consolidated } \\
\text { budget, RUB } \\
\text { bn }\end{array}$ & 593,2 & 801,8 & 1036,4 & 1343,0 & 1664,2 & 1783,5 & 1893,9 & 2231,8 \\
\hline Federal budget & 121,6 & 162,1 & 212,4 & 294,6 & 355,0 & 418,0 & 442,8 & 553,4 \\
\hline $\begin{array}{l}\text { Consolidated } \\
\text { budget of } \\
\text { subjects of the } \\
\text { Russian } \\
\text { Federation }\end{array}$ & 471,6 & 628,6 & 810,1 & 1032,5 & 1292,2 & 1345,9 & 1450,9 & 1726,4 \\
\hline $\begin{array}{l}\text { The share of } \\
\text { consolidated } \\
\text { budget } \\
\text { expenditures } \\
\text { \% of GDP) }\end{array}$ & 3,5 & 3,7 & 3,9 & 4,0 & 4,0 & 4,6 & 4,1 & 4,0 \\
\hline $\begin{array}{l}\text { The share of } \\
\text { education } \\
\text { expenditures in } \\
\text { the } \\
\text { consolidated } \\
\text { budget of the } \\
\text { Russian } \\
\text { Federation (\%) }\end{array}$ & 12,7 & 11,8 & 12,4 & 11,8 & 11,8 & 11,1 & 10,8 & 11,2 \\
\hline
\end{tabular}

It should be emphasized that the demand for higher education in Russia steadily increased and household expenditures on education grew in absolute volumes, although they did not change as a percentage of GDP (Table 3). 
The Model of the Formation and Implementation of the Creative and Innovative Potential of the Russian System of Higher Education

92

Table 3. Household expenditure on education services in 2000-2011 based on data from Indicators of education (2013)

\begin{tabular}{|l|c|c|c|c|c|c|c|c|}
\hline & $\mathbf{2 0 0 0}$ & $\mathbf{2 0 0 2}$ & $\mathbf{2 0 0 4}$ & $\mathbf{2 0 0 7}$ & $\mathbf{2 0 0 8}$ & $\mathbf{2 0 0 9}$ & $\mathbf{2 0 1 0}$ & $\mathbf{2 0 1 1}$ \\
\hline $\begin{array}{l}\text { Amount of } \\
\text { commercial } \\
\text { educational } \\
\text { services, } \\
\text { RUB mln }\end{array}$ & 41,5 & 72,9 & 118,7 & 241,6 & 287,5 & 310,2 & 326,1 & 347,3 \\
\hline$\%$ of GDP & 0,6 & 0,7 & 0,7 & 0,7 & 0,7 & 0,7 & 0,7 & 0,6 \\
\hline
\end{tabular}

The extra budgetary income compensated for the lack of public funding to some extent, which was less than half of the required amount, reflecting the assessment of this sector still as "costly", which did not contribute to advancing the goals of the forward-looking development of Russian higher education up to today.

A wide range of measures were implemented in the field of the renewal and strengthening of university science in the twenty-first century - from Concept of the development of the university science sector in the context of the transition to a market economy (1992) to the implementation of such documents as Concept for scientific, scientific-technical, and innovation policy in the education system for 2001-2005 (2000), Doctrine of Russian Science Development, Concept of reforming of Russian science, Concept of the innovation policy of the Russian Federation, Main conceptual provisions of the regional scientific and technical policy of higher education and others. Accordingly, the first decade of the twenty-first century was a time of the particular strengthening of university science and the growth of many of its indicators. Tables 4 and 5 show that in this period there was an increase in the internal current and capital expenditures for research and development.

Table 4. Internal research and development expenditure in 1995-2002 (RUB mln, 1995 - RUB bln) based on data from Education in Russia (2003)

\begin{tabular}{|l|r|r|r|r|}
\hline \multicolumn{1}{|c|}{ In then-current prices } & $\mathbf{1 9 9 5}$ & $\mathbf{2 0 0 0}$ & $\mathbf{2 0 0 1}$ & $\mathbf{2 0 0 2}$ \\
\hline $\begin{array}{l}\text { The total amount of the internal expenditures } \\
\text { for research and development }\end{array}$ & 12149,5 & 76697,1 & 105260,7 & 135004,5 \\
\hline including: & 11672,1 & 73873,3 & 100507,4 & 128243,3 \\
\hline internal current expenditures constant prices of 1989 \\
\hline capital expenditures & 477,4 & 2823,8 & 4753,3 & 6761,2 \\
\hline $\begin{array}{l}\text { The total amount of the internal expenditures } \\
\text { for research and development }\end{array}$ & 2,49 & 3,32 & 3,87 & 4,31 \\
\hline including: & 2,39 & 3,20 & 3,69 & 4,09 \\
\hline internal current expenditures & 0,10 & 0,12 & 0,18 & 0,22 \\
\hline capital expenditures &
\end{tabular}


Table 5. Internal research and development expenditure in 2005-2012 (RUB mln in current prices) based on data from Indicators of science (2013)

\begin{tabular}{|c|c|c|c|c|}
\hline & 2005 & 2008 & 2011 & 2012 \\
\hline \multicolumn{5}{|c|}{ In current prices } \\
\hline $\begin{array}{l}\text { The total amount of the internal } \\
\text { expenditures for research and } \\
\text { development }\end{array}$ & 230785,1 & 431073,2 & 610426,7 & 699869,8 \\
\hline \multicolumn{5}{|l|}{ including: } \\
\hline internal current expenditures & 221119,5 & 410864,9 & 568386,7 & 655061,7 \\
\hline capital expenditures & 9665,6 & 20206,2 & 42039,9 & 44808,0 \\
\hline
\end{tabular}

However, at the beginning of the twenty-first century there was a significant reduction in the number of personnel engaged in research and development (Table 6) which should be taken into account, although it included the growing number of Doctors of Science.

Table 6. Number of personnel engaged in research and development in 1995-2002 (persons) based on data from Education in Russia (2003)

\begin{tabular}{|l|c|c|c|c|c|}
\hline & \multirow{2}{*}{$\begin{array}{c}\text { Personnel engaged in } \\
\text { research and } \\
\text { development }\end{array}$} & researchers & technicians & $\begin{array}{c}\text { support } \\
\text { personnel }\end{array}$ & others \\
\cline { 3 - 6 } Total & & & & & \\
\hline 1995 & 1061044 & 518690 & 101371 & 274925 & 166058 \\
\hline 2000 & 887729 & 425954 & 75184 & 240506 & 146085 \\
\hline 2001 & 885568 & 422176 & 75416 & 238933 & 149043 \\
\hline 2002 & 870878 & 414676 & 74599 & 232636 & 148967 \\
\hline \multicolumn{7}{|c|}{ those who had a degree: } \\
\hline \multicolumn{7}{|c|}{ Doctor of Sciences (Dr. Sc.) } \\
\hline 1995 & 19405 & 19330 & - & 57 & 18 \\
\hline 2000 & 22018 & 21949 & 4 & 46 & 19 \\
\hline 2001 & 22329 & 22262 & 8 & 38 & 21 \\
\hline 2002 & 22645 & 22571 & 6 & 49 & 19 \\
\hline \multicolumn{7}{|c|}{ Candidate of Sciences (PhD, Cand. Sc.) } \\
\hline 1995 & 97927 & 97135 & 31 & 587 & 174 \\
\hline 2000 & 84930 & 83962 & 69 & 663 & 236 \\
\hline 2001 & 83091 & 82152 & 84 & 601 & 254 \\
\hline 2002 & 80750 & 79775 & 67 & 651 & 257 \\
\hline
\end{tabular}

The trend of the reduction of personnel engaged in research and development continued in subsequent years, as shown in Table 7.

Table 7. Number of personnel engaged in research and development in 2005-2012 (persons) based on data from Indicators of science (2014)

\begin{tabular}{|l|c|c|c|c|c|}
\hline \multirow{2}{*}{$\begin{array}{c}\text { Personnel engaged } \\
\text { in research and }\end{array}$} & \multicolumn{4}{|c|}{ including } \\
\cline { 3 - 6 } & researchers & technicians & support & others \\
\hline
\end{tabular}


The Model of the Formation and Implementation of the Creative and Innovative Potential of the Russian System of Higher Education

94

\begin{tabular}{|l|c|c|c|c|c|}
\hline & development & & & personnel & \\
\hline 2005 & 813207 & 391121 & 65982 & 215555 & 140549 \\
\hline 2008 & 761252 & 375804 & 60218 & 194769 & 130461 \\
\hline 2010 & 736540 & 368915 & 59276 & 183713 & 124636 \\
\hline 2011 & 735273 & 374746 & 61502 & 176494 & 120471 \\
\hline 2012 & 726318 & 372620 & 58905 & 176790 & 119003 \\
\hline
\end{tabular}

Despite the positive dynamics of the development of higher education in Russia, there are still some systemic problems, which are difficult to resolve. For example, the problem of the qualitative organization of the competitive distribution of the state order for preparation of graduates, which in turn is closely connected with the need to have full and accessible information that reflects the real extent, quality and perspectives of training of the qualified personnel and their compliance with the demand in the labor market. This decision is being attempted to get regionalized, but it challenges the unity of both the educational and economic field of Russia.

However, this issue, like other problems, is addressed by conventional methods that are not correlated with the emerging new type of economy and society in which the really productive resource is only the knowledge which contains the novelty of the transformative value (otherwise, the economic system would have mainly obsolete knowledge). In addition, a new type of economy is impossible without the reproduction of a particular kind of competence, namely the competence to manage the production and realization of the transformative novelty value of knowledge, i.e. general universal transformative (creative and innovative) competences. On this basis, the economy of the novelty of knowledge and universal transformative (creative and innovative) competencies is understood as the deep essence of the emerging "knowledge economy". It is a new type of economy and society based on a new transformative (intellectually innovative and creatively innovative) method of the public (universal) reproduction and on the results of the intellectual activity, which have an innovative content that are guaranteed by technological and economic application and bringing added value.

In the new era, the era of the reproduction of innovations and the integrating creative and innovative kind of labor, to achieve the imperatives, laid down in its formation type and social code, there is a need for a new type of the university that can not only recover its lost categorical flexibility, but also transform it to a higher qualitative level which is appropriate to the novelty, versatility and interdependence of the imperatives of the new era.

The economic model of the new type of the university must embody a really integrating and universally unique tool to become a truly fundamental and universal response to the challenges of the new era. The current dominating views on the necessary model of the university, as well as the practically implemented models of the university, are clearly insufficient for such a fundamental answer. The reasons for this are that the practical needs of society (particularly its business structures) are 
presently focused on workers with a narrowly instrumental and single-discipline orientation, who meet situational and short-term needs for the replacement of the existing specific posts, which become multiple and segmented. This turned modern universities into multidisciplinary professional educational institutions with many narrow professional training areas. In such a way, the modern university lost its categorical flexibility.

This tendency of the substitution of the university flexibility for the pragmatism of the narrowly instrumental goals that meet short-term interests of corporate capitalism and the utilitarian state is now a defining issue, analyzed in many studies (Senashenko, 2012; Readings, 2009; Kolesnikova, 2013). The Japanese experience (which is a definite alternative) when a graduate is prepared on a wide basis as a "generalist" (a "generalist" in contrast to a "specialist"), who is then trained for special tasks within the enterprise itself in the framework of internal training, remains on the periphery of global processes. This is also due to the fact that the economic pragmatism of business in general global terms (and Japan is no exception) increasingly requires the reduction in the cost of the internal training, and, therefore, is set to receive more instrumentally trained workers from the university. The economic pragmatism of the utilitarian state, in its turn, requires a more economical use of public funds for these purposes.

The economic pragmatism itself, direction of which coincides with the business of its serving state, requires a short-cut (and, accordingly, the reduction in expenditure) from fundamental research and its results to applied research results and their implementation in the design and experimental development of specific products. In fact, at the same time there is an increase in both the need to reduce the life cycle of the reproduction of innovations, and the need to reduce their cost.

It is a mistake to believe that the current economic pragmatism is marked only as instantaneous - it actually embodies the universality of the tendency, successively connecting all formational genotypes, to the enhanced demand for the increased level of the economic efficiency of the functioning and development of each unit of social reproduction. In addition, this tendency is fundamental: each unit of social reproduction (as the system, structure, process, stage, and result) should become more social-efficient and cost-effective in the socio-historical evolution. In the new era, these two types of efficiency should be directly integrated - and if not to consider this regular tendency, it is impossible to correctly interpret the specific historical role of the modern economic pragmatism of the corporate-capitalist system (both in the image of business, and in its another image - the utilitarian state). It is also impossible to distinguish the real role of innovation and the real purpose of the new era as the era of innovation among these images of the specifically situational contemporary reality.

Therefore, the university models, which are presently dominant in the public debate, should be analyzed in this context. They are, in our view, can be divided into two main groups: realistic and pragmatic models and non-pragmatic models. Both groups, 
despite having rational kernels, can no longer provide a fundamental integrating response to the challenges of the new era.

Models of the first group, characterized as realistic and pragmatic, can be reduced to the two basic models, which now entered into the world, including Russian, socioeconomic practice and are offered as the most advanced and preferred models: the model of the research university and the model of the entrepreneurial university.

The model of the research university, despite seeming fundamental (because it relies on the fundamental role of science in general and in its special applied demand in modern economy), stands still as one-sided, as it focuses on the one side, on a research single unit. Although this unit, in fact, is a generating unit in innovation, the model itself is still of the integrating nature. Even if to transform this model into more comprehensive, based on a fairly common idea that all forms of practice, as well as all types of training, must be of the exploratory nature nowadays, it does not get the desired perfection, because the very concept of "research" has no indication of the result or the product coming into practice, and, therefore, there is the isolation of science as the research from practice as a real transformative activity. At the same time, this realizable model is still both realistic and pragmatic, and for the present outgoing era is quite optimal. Therefore, the literature indicates that "the research university is the most perfect model of higher education that meets the needs of society, human needs and the needs of the state for the scientific, technological, technical and innovative activity in all forms and levels of education" (Mayer \& Babanskii, 2006).

The entrepreneurial university model, more pragmatic than the model of the research university, is focused on another separate unit - the unit of the direct or indirect commercialization of created innovations and even more, on the direct commercialization of all activities of the university, but without the reconstruction and development of its universal origin. And thus it is (despite its instantaneous and longterm relevance and progressiveness as the model of the implemented economic efficiency) even more one-sided than the first model, as in the context of the implementation of the business functions the university could, in principle, be satisfied with the borrowing of foreign scientific innovations and desist from its fundamental research functions. Entrepreneurship is one of the most important real-practical embodiments of the transformative (creative and innovative) activities, but it has no universality. Konstantinov and Filonovich (2007) deeply analyzed both theoretical approaches to the definition of the entrepreneurial university and the issues related to the practical embodiment of the status of the entrepreneurial university in the Russian education system. They conclude that "taking into account which areas of activity are key to higher education, we can say that the university which wants to be called entrepreneurial should overcome the limitations in three areas: 
- the generation of knowledge, constantly working on the development of new research methods and the examination of new areas of knowledge or new challenges in already known areas;

- teaching, developing the innovative teaching methods and modifying the learning content by revealing the latest achievements of science and practice;

- the implementation of knowledge into practice by means of various kinds of interaction with the environment.

That is, these scientists believe that the entrepreneurial university cannot but be of the research nature - and then the one-sidedness of the "business" model is overcome.

Nevertheless, it is important that both these concepts (models) of the university, despite their one-sidedness, are at least viable and demanded by the social and economic practice. After all, they are currently opposed to the views that are still defending the model of the university as the center of some "classic" universality, wherein the abstract spirit of science and education, freely rising to its own heights in the form of the "public good", revels in its nature and hangs over the actual activity practice, not directly connecting to it, but restricting to thinking processes, which are not integrated with the economic turnover. In these models, the required flexibility of the university affairs can be interpreted only as an abstract (in fact, unrealistic and impossible as it stands) "comprehensiveness". Therefore, the vagueness of graduates training, in its turn, resulting from the understanding of the university function as a center of "freethinking", "the search for truth for the sake of the truth" and "methodological knowledge", i.e., as a center of the formation of not so much the specific professional culture but as the general professional and even common culture, a center that is not limited in its activities by economic, narrow pragmatic tasks and not targeted by them.

Despite the apparent attractiveness of the second group, which we characterize as "non-pragmatic", these models clearly reflect the views denying the growing pragmatism of the economy and social life in general. Thus they negate the principle of a steady increase in the integrated social and economic efficiency of the units of social reproduction that makes these views and models demanded by neither the present nor the future social and economic practice, and as a result, futile and shortterm. They are not only impractical in all senses, but also economically more costly as they lengthen and complicate the way of the direct realization of the general (common cultural and general professional) competencies of graduates in specific professional, specialized areas and fields requiring the mediating units to get the personnel "fit" for those areas and the demanded instrumental functions and, accordingly, extra costs for maintenance of these units.

The confrontation of the above concepts (models) of the university reveals the real socio-economic gap between fundamentality and instrumentalism and, more than that, the gap between ideas (science, analytics, etc.) and socio-economic practice, which requires a radical transformation of both the modern university and the relations of 
modern society in general. As far as neither one nor the other of the considered groups of models of the university cannot give an adequate fundamental integrating response to the challenges of the new era, this function should be implemented by a really productive university model of the new generation, which we characterize as the university of the transformative (creative and innovative) type. Its integrating potential and the ability to overcome the profound discontinuity between fundamentality and instrumentalism, expressed in the confrontation of the non-pragmatic and realistically pragmatic concepts of the university, are identified and revealed in Figure 4.

Figure 4. The integrating potential of the model of the transformative (creative and innovative) university, which could be a response to the challenges of the new era (compiled by A.P. Gorbunov)
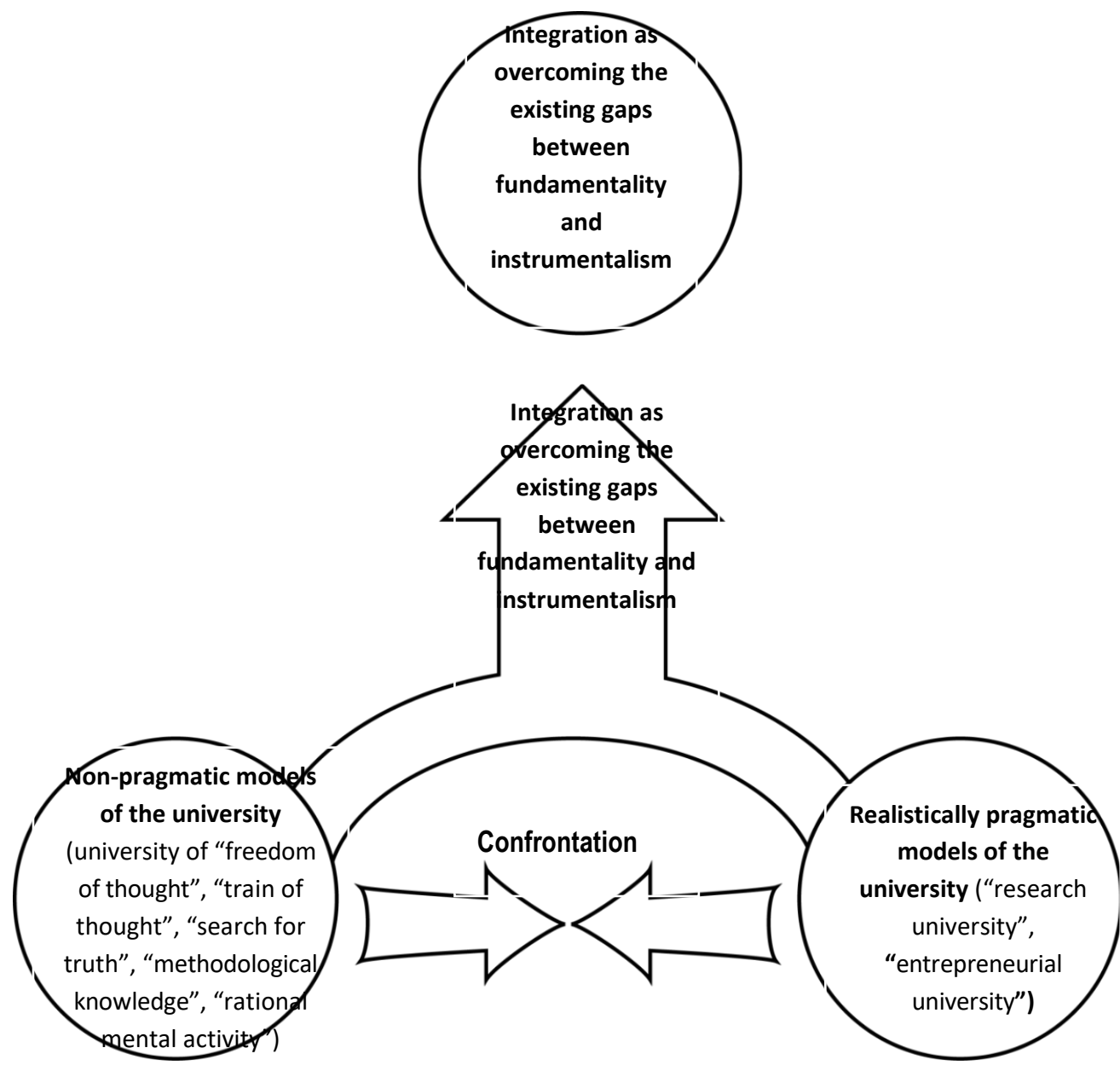

As it stands, the model of the transformative (creative and innovative) university acts as an integrating self-renewing socio-humanitarian and socio-economic 
technological tool of the reproduction of processes and relations of the transformative (creative and innovative) activities ensuring the generation of the transformative value of knowledge novelty and its transmission (transfer) into the real economy and social sphere in the form of innovation technologies and competences. Thus, this economically substantiated model of the advanced environment of a multicultural professional community and civil society cultivates the universal unique organizers of innovations and communications, who act as developers, carriers and transmitters of the key transformative (creative and innovative) activity-based and communicative competences, able and willing to implement them in the diverse spheres of activity and communication, transforming these areas by themselves.

Thus, this model allows integrating and overcoming a wide range of social and economic gaps in the public system, precisely because its fundamental bases meet the essence of the new era. Relying on them, one can almost manage to bridge the gap in the organization of the modern university.

\section{References}

Abramenko, V., and N. Ilyina, 2001. "Shaky well-being: Russia is entering a new year with a good performance but an unclear perspective”. Segodnya [Today]. № 1, 4 January.

Annual Address of the President of the Russian Federation to the Federal Assembly of the Russian Federation of April 3, 2001. Moscow, 2001. p. 13.

Concept for scientific, scientific-technical, and innovation policy in the education system of the Russian Federation for 2001-2005, approved by Order of the Russian Ministry of June 6", 2000. № 1705. Science in education. Part 1. The organizational base. Moscow: Russian Ministry of Education, pp. 83-96.

Education in figures, 2013, Moscow: The National Research University Higher School of Economics.

Etzkowitz, H., 2003, “Research Groups as 'Quasi-firms': The invention of the entrepreneurial university". New York: Wiley.

Etzkowitz, H., and L. Leydesdorff, 1998, "Emergence of a Triple Helix of UniversityIndustry-Government Relations". Science and Public Policy, 22(13), 85-97.

Indicators of education, 2013, Statistics digest. Moscow: The National Research University Higher School of Economics, pp. 72-80.

Indicators of science, 2014, Moscow: The National Research University Higher School of Economics, pp. 98.

Klyachko, T.L., 2011, "Education in the Russian Federation: problems and trends of the development in the early twenty-first century". Mir Rossii [World of Russia], 20(1), pp. 88.

Kolesnikova, E.Y., 2013, "Modern University: In search of meaning and reason”. Akademia [Academy], 3, pp. 6.

Konstantinov, G.N., and S.R. Filonovich, 2007, "What is the entrepreneurial university?" Voprosy Obrazovaniya [Questions of Education], 1, pp. 52.

Mayer, G.V., and M.D. Babanskii, 2006, "Innovation and the mission of the university". Universitetskoye Upravlenie [University Management], 6(46), pp. 11.

Readings, B., 2009, “The university in ruins". Minsk: Nauka. 
100

Röpke, J., 1998, "The entrepreneurial university, innovation, academic knowledge creation and regional development in a globalized economy". Working Paper 15 Department of Economics, Philipps-Universität Marburg, Germany.

Schulte, P., 2004, "The Entrepreneurial University: a Strategy for Institutional Development". Higher Education in Europe. 29(2), pp. 188.

Senashenko, V., 2012, "On the problems of the formation of the modern university". Rektor vuza [Rector of the university], 12, pp. 38-43.

Statistical Yearbook of Russia, 2014, "Digest of articles". Russian Statistics. Chapter: Main socio-economic indicators. Moscow: Astrel, p. 35. 